\title{
Obtaining hydroxyapatite with different precursors for application as a biomaterial
}

\section{(Obtenção de hidroxiapatita com diferentes precursores para aplicação como biomaterial)}

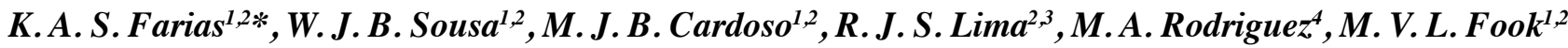 \\ ${ }^{I}$ Federal University of Campina Grande, Department of Materials Science and Engineering, Paraíba, Brazil \\ ${ }^{2}$ Federal University of Campina Grande, Laboratory of Biomaterials Evaluation and Development of the \\ Northeast, Paraíba, Brazil \\ ${ }^{3}$ Federal University of Campina Grande, Department of Physics, Paraíba, Brazil \\ ${ }^{4}$ Instituto de Cerámica y Vidrio, CSIC, Madrid, Spain
}

\begin{abstract}
The hydroxyapatite (HAp) is a ceramic biomaterial with wide application in the bone regeneration. It can be obtained by different routes and different precursors. In this study, the synthesis of HAp was carried out by precipitation and subsequent thermal treatment using different calcium precursors: calcium hydroxide from synthetic origin and calcium oxide obtained from the eggshell. The obtained materials were characterized by X-ray diffraction (XRD), scanning electron microscopy (SEM), and Fourier-transform infrared (FTIR) spectroscopy. By SEM, variations of the crystal size and the concentration of agglomerates were observed. FTIR and XRD analyses proved the formation of HAp and how the (mineral and biological) precursors affected the microstructure. The thermal decomposition process of the calcium oxide obtained from the eggshell showed to be more effective for the synthesis of the hydroxyapatite, resulting in more stable morphology and microstructure.
\end{abstract}

Keywords: hydroxyapatite, synthesis, biomaterials.

\section{Resumo}

A hidroxiapatita (HAp) é um biomaterial cerâmico com ampla aplicação na regeneração óssea. Pode ser obtida por diferentes rotas e diferentes precursores. Neste estudo, a síntese da HAp foi realizada por precipitação e tratamento térmico subsequente utilizando diferentes precursores de cálcio: hidróxido de cálcio de origem sintética e óxido de cálcio obtido da casca do ovo. Os materiais obtidos foram caracterizados por difração de raios $X(D R X)$, microscopia eletrônica de varredura (MEV) e espectroscopia no infravermelho com transformada de Fourier (FTIR). Por MEV, foram observadas variações do tamanho dos cristais e da concentração de aglomerados. Análises por FTIR e DRX comprovaram a formação de HAp e como os precursores (mineral e biológico) influenciaram a microestrutura. O processo de decomposição térmica do óxido de cálcio obtido da casca do ovo mostrouse mais efetivo para a síntese da hidroxiapatita, resultando em morfologia e microestrutura mais estáveis.

Palavras-chave: hidroxiapatita, síntese, biomateriais.

\section{INTRODUCTION}

The bones and teeth of all vertebrates are natural composites formed by collagen molecules bound in linear chains arranged in fibers; among these molecules there are small, regularly spaced interstitial compartments, where nanocrystals of an inorganic solid are present, which represents $65 \%$ of the total bone mass [1-3]. Tissue engineering aims to overcome the limitations of conventional treatments, which are based on reconstructive surgery or organ transplantation, making possible the production of substitutes for certain organs and tissues, allowing the implantation in the patient without risk of rejection by the

* (DD https://orcid.org/0000-0002-9337-6386 organism, immunological tolerance $[4,5]$. Biomaterials are inherent in several areas, belonging to a multidisciplinary field such as chemistry [6], chemical engineering [7-9], mechanical engineering [10-13], materials science [14, 15], bioengineering and biology [16, 17], medicine [18-20], and with diverse considerations, such as ethics, bioethics and governmental regulation [21]. Among the calcium phosphate bioceramics, the hydroxyapatite (HAp) [17, 2224] is highlighted in the research area because it is similar to main mineral phase constituent of the bone, with a wide use in the medical and dental areas [25-27]. HAp is a calcium phosphate hydrated from the mineral group of apatite with chemical formula $\mathrm{Ca}_{10}\left(\mathrm{PO}_{4}\right)_{6}(\mathrm{OH})_{2}$ and $\mathrm{Ca} / \mathrm{P}$ ratio of 1.67 $[3,28]$. It is a bioactive ceramic material widely used in the form of particles in several devices of the bone regeneration 
or coating of metallic implants to improve their biological properties [29-31].

There are different techniques for obtaining hydroxyapatite, such as wet precipitation method (acid-base reaction) [32], reaction between phosphate salts [33], dry synthesis [34], sol-gel method [35], and hydrothermal method [36]. Wet precipitation method in aqueous solution stands out for its relative simplicity, which has low cost and good reproducibility. Besides it allows obtaining a homogeneous, reactive biomaterial with a well-defined stoichiometric composition. This way it allows the control of synthesis, which involves reactions between calcium and phosphorus precursors, through the control of temperature and $\mathrm{pH}$ of the solution [30,37-40]. The calcium precursor commonly used to obtain hydroxyapatite is calcium hydroxide from synthetic origin or biological origin such as sea shell and eggshell $[8$, 41-47]. The use of eggshell is suggested as an alternative for solid waste assessment; it represents $10 \%$ of the weight of the egg, generating a waste quantity of 5.92 million tons per year worldwide $[48,49]$. The objective of the present work is to obtain hydroxyapatite by precipitation using two different Ca precursors: calcium hydroxide from synthesis and calcium oxide from eggshell. The obtained materials were characterized by X-ray diffraction (XRD), scanning electron microscopy (SEM), Fourier-transform infrared (FTIR) spectroscopy, and performing a crystallographic analysis of the obtained materials by the Rietveld method, with GSAS II [50] and VESTA programs [51].

\section{MATERIALS AND METHODS}

For the synthesis of HAp phosphoric acid $\left(\mathrm{H}_{3} \mathrm{PO}_{4}\right.$ P.A. ISO, Vetec) was used; for Ca source two kinds of precursors were used: synthetic calcium hydroxide $\left[\mathrm{Ca}(\mathrm{OH})_{2}\right.$ P.A., Vetec], and chicken eggshell from eggs purchased on the market.

Synthesis of hydroxyapatite: the $\mathrm{Ca}(\mathrm{OH})_{2}$ from eggshell was obtained as follow: the eggshells were washed with distilled water, dried at $50{ }^{\circ} \mathrm{C}$, crushed in a porcelain mortar and then sieved through a 100 mesh screen to obtain the powder. This powder was heated at $800{ }^{\circ} \mathrm{C}$ for $3 \mathrm{~h}$, with a heating rate of $10{ }^{\circ} \mathrm{C} / \mathrm{min}$ to obtain the calcium oxide $(\mathrm{CaO})$ which reacted with distilled water under constant stirring, in order to reach its total conversion to $\mathrm{Ca}(\mathrm{OH})_{2}$. The HAp powders where named in order to differentiate by the precursor used: the sample 1 from $\mathrm{Ca}(\mathrm{OH})_{2}$ obtained from eggshell (biological origin) and sample 2 from $\mathrm{Ca}(\mathrm{OH})_{2}$ from Vetec (synthetic origin). The precipitation of HAp powder was carried out through neutralization reaction between $\mathrm{Ca}(\mathrm{OH})_{2}$ and $\mathrm{H}_{3} \mathrm{PO}_{4}$ solutions in distilled water; the amounts of solutions were obtained by calculation determined according to the stoichiometry value of the molar ratio between calcium and phosphorus, $\mathrm{Ca} / \mathrm{P}=1.67$. The phosphoric solution was added on the basic solution with a controlled dosage (approximately $1.0 \mathrm{~mL} / \mathrm{min}$ ), at approximately $80{ }^{\circ} \mathrm{C}$ under magnetic stirring. After the complete addition, the product obtained was stirred during
$24 \mathrm{~h}$ to complete the reaction. It was then maintained for $24 \mathrm{~h}$ at room temperature and placed in an oven at $110^{\circ} \mathrm{C}$ for $24 \mathrm{~h}$. The calcined product was crushed and passed through a 100 mesh sieve and calcined at $900{ }^{\circ} \mathrm{C}$ for $2 \mathrm{~h}$.

Microstructural studies were carried out using a scanning electron microscope (TM 1000, Hitachi). The obtained images were analyzed using ImageJ software (National Institute of Mental Health, USA) in order to obtain particle size distribution of the obtained powders. Infrared characterization was carried out using a FTIR spectroscope (Spectrum 400, Perkin Elmer). The identification of the samples by X-ray diffraction was performed on a Shimadzu XRD-7000 diffractometer, at $40 \mathrm{kV}$ with a current of $30 \mathrm{~mA}$ and $\mathrm{CuK} \alpha$ radiation $(\lambda=1.5406 \AA)$. Diffractograms were acquired in the range between $5^{\circ} \leq 2 \theta \leq 60^{\circ}$ with step of $0.02^{\circ}$ and scanning velocity of $1 \% \mathrm{~min}$. Rietveld structural refinement was carried out using GSAS II (General System Analyzer Structure) software. The main objective of the Rietveld method is the refinement of crystalline structures by means of theoretical models using the least square method to adjust the theoretical diffraction pattern to the experimental one. The numerical indicator Rwp is statistically the most significant [52]. Besides the numerical criteria, it is considered of fundamental importance the graphical adjustment criterion, which represents the difference between the calculated and observed data curves. Rietveld's refinement for HAp was done based on data from [53] with the hexagonal space group P63/m, having two independent crystallographic sites for $\mathrm{Ca}$, one for $\mathrm{P}$, four for $\mathrm{O}$ and one for $\mathrm{H}$. The single unit cell of HAp consisted of 44 atoms, with $10 \mathrm{Ca}$ atoms, 6 of phosphate tetrahedral $\left(\mathrm{PO}_{4}^{3-}\right)$, and 2 groups of $\mathrm{OH}^{-}$well-organized in the hexagonal atomic structure.

\section{RESULTS AND DISCUSSION}

The morphology of the powders obtained by the different precursors are shown in Fig. 1, images obtained by SEM. It was observed that the morphology of the HAp particles obtained by the different precursors was similar, having almost spherical shape, having in both a wide distribution of size, agglomerated particles and with the presence of porosity of different dimensions, being smaller than 1-2 $\mu \mathrm{m}$. Oliveira et al. [54], when synthesized the hydroxyapatite via wet reaction, observed a morphology of the powder with a porous structure and with varied pore size, as well as observed in the present study. According to $[42,49]$, the presence of pores smaller than $30 \mu \mathrm{m}$ should be highlighted because they allow better neovascularization and growth of fibroblasts inside the supports, when these are applied as biomaterials. Corroborating also with the studies of [41] which synthesized HAp using $800{ }^{\circ} \mathrm{C}$ as decomposition temperature, it was verified that the particles were agglomerated and had almost spherical morphology.

From the SEM images of the obtained HAp samples, a study of the size of particle clusters was carried out with ImageJ software. Fig. 2 shows the size distribution of the 

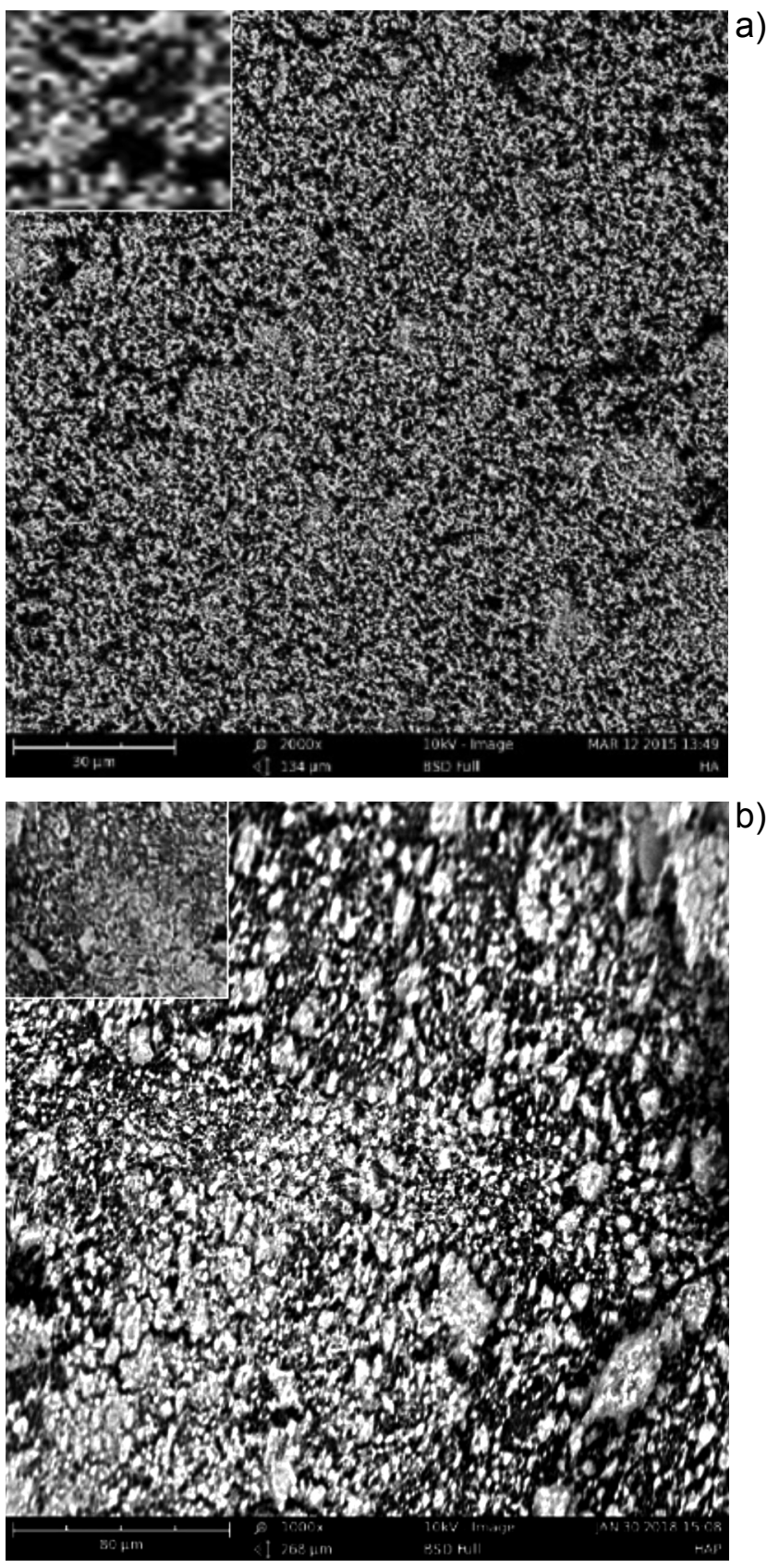

Figure 1: SEM micrographs showing powder morphology of: a) HAp (egg shell); and b) HAp (synthetic origin).

[Figura 1: Micrografias de MEV mostrando a morfologia do pó de: a) HAp (casca de ovo); e b) HAp (origem sintética).]

equivalent spherical diameter for samples 1 and 2 . The obtained distributions suggested the formation of particle agglomerates with a wide monomodal distribution of size and medium size of agglomerates (D50) of $0.2 \mu \mathrm{m}$ in sample 1 and $0.1 \mu \mathrm{m}$ in sample 2 . SEM results showed that the hydroxyapatite obtained by the biological precursor (sample 1) showed a greater morphological uniformity of the particle agglomerates even with larger agglomerate sizes when compared to the mineral precursor (sample 2), which can effectively influence their biological and mechanical responses. Manhães et al. [55] synthesized calcium phosphates by wet neutralization reaction, from the precursor calcium chloride $\left(\mathrm{CaC}_{12} \cdot 2 \mathrm{H}_{2} \mathrm{O}\right)$ with atomic ratio $\mathrm{Ca} / \mathrm{P}$ of 1.67 , and calcination at $800{ }^{\circ} \mathrm{C}$, and observed by granulometric analysis a wide distribution of agglomerate sizes, with values of mean diameter of $12 \mu \mathrm{m}$; in the samples obtained in this work, the mean diameter of the agglomerates was $0.9 \mu \mathrm{m}$, which consequently had enhanced surface area that favors absorption by the organism. The tendency of particle agglomeration was higher for the smaller particles, which agreed with the literature $[3,49,56]$.

The infrared spectroscopy result of the sample obtained by eggshell is shown in Fig. 3a. The spectrum of the hydroxyapatite synthesized from eggshell was similar to those found in [57]. By analyzing the spectrum, it was observed the absorptions relative to the phosphate group, with the characteristic group $\mathrm{PO}_{4}^{3-}$, indicated in Table I, corroborating with [54]. The infrared spectroscopy result of the sample obtained by calcium hydroxide is shown in Fig. 3b. This spectrum shows an enlargement of the bands referring to the group $\mathrm{PO}_{4}^{3-}$ between 950 and $1200 \mathrm{~cm}^{-1}$ indicated in Table I, and a band in the $3600 \mathrm{~cm}^{-1}$, relative to the $\mathrm{OH}$ group of the lower intensity hydroxyl $[58,59]$. It was possible to notice that the FTIR spectra of the two samples were similar. In the samples obtained by the two

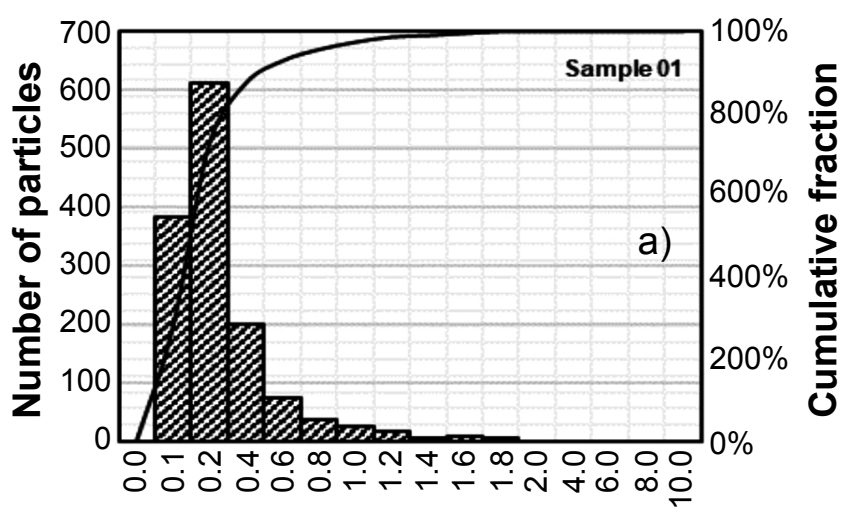

Particle size $(\mu \mathrm{m})$

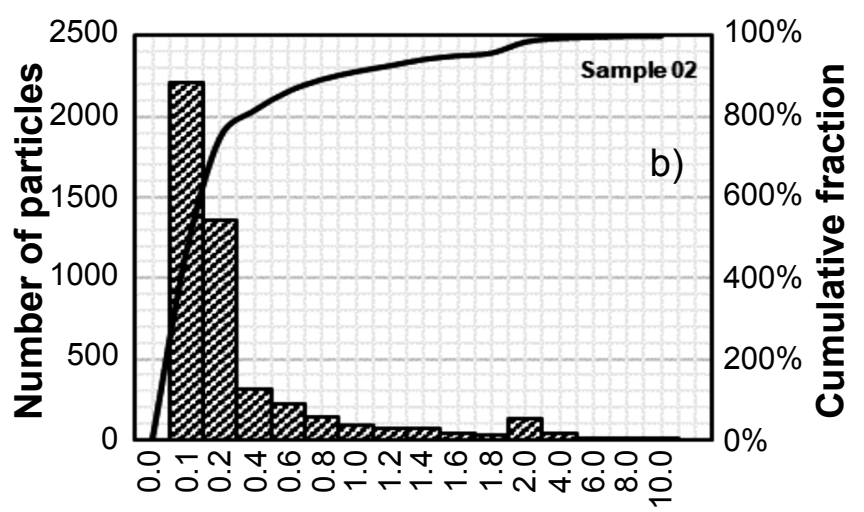

Particle size $(\mu \mathrm{m})$

Figure 2: Particle size distribution curves obtained from measured areas in micrographs of powders obtained by: a) route 1 ; and b) route 2 .

[Figura 2: Curvas de distribuição de tamanho de partícula obtidas de áreas medidas em micrografias dos pós obtidos pela: a) rota 1; e b) rota 2.] 
routes the characteristic peaks of HAp were present. An observed difference between the HAp obtained was related to the presence of a peak in the region of 1600 and $3400 \mathrm{~cm}^{-1}$, relative to the $\mathrm{OH}$ group of the lower intensity hydroxyl in sample 2, possibly from the presence of structural $\mathrm{H}_{2} \mathrm{O}$; bands at 1470 and $1420 \mathrm{~cm}^{-1}$ of symmetrical stretching of the C-O group were also identified [56, 60,61]. According to the result of the FTIR it was observed that the hydroxyapatite obtained by the biological precursor had less amount of hydroxyl group $(\mathrm{OH})$ in the structure, which may be associated with increased crystallinity of the same, corroborating with the XRD results and confirming the greater stability of the microstructure when compared to the mineral precursor.
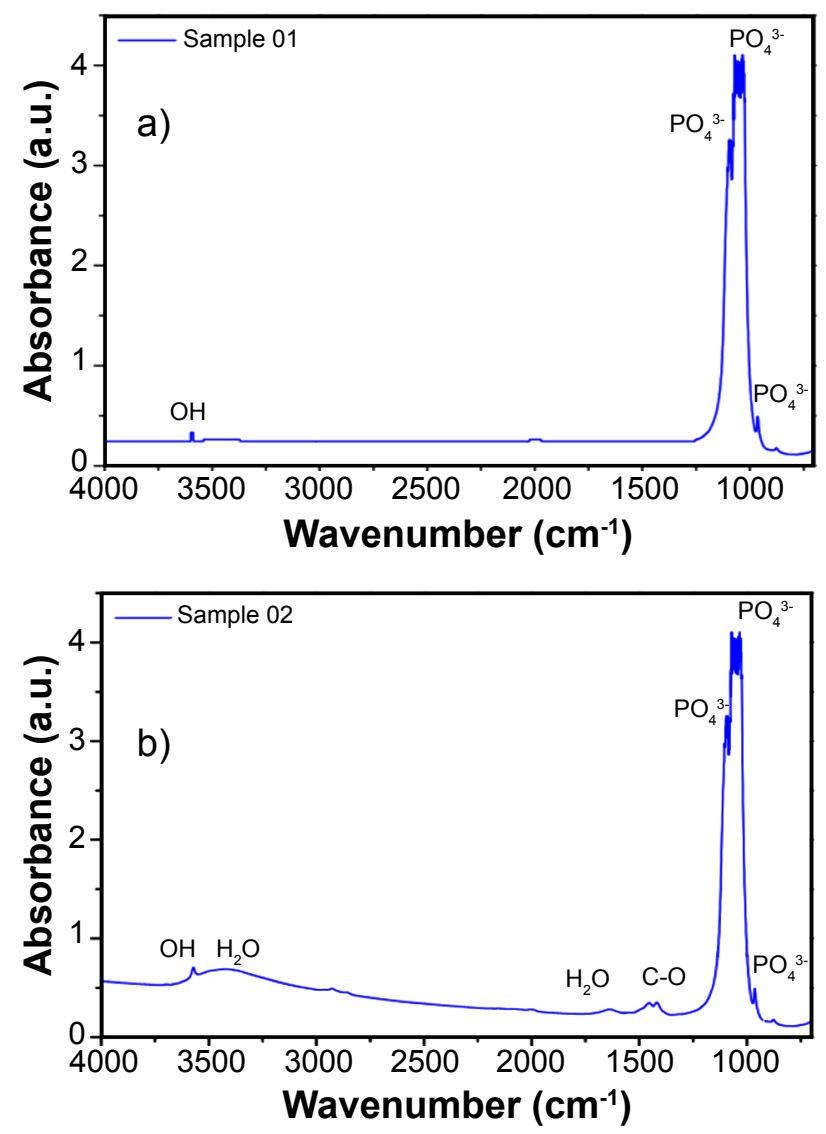

Figure 3: FTIR spectra of powders: a) sample 1; and b) sample 2.

[Figura 3: Espectros de FTIR dos pós: a) amostra 1; e b) amostra 2.]

Table I - F TIR absorption bands of sample 1.

[Tabela I - Bandas de absorção de FTIR da amostra 1.]

\begin{tabular}{cl}
\hline Absorption band $\left(\mathrm{cm}^{-1}\right)$ & \multicolumn{1}{c}{ Assignment } \\
\hline 1088 & Asymmetrical stretching of $\mathrm{PO}_{4}^{3-}$ \\
1022 & Symmetrical stretch $\mathrm{PO}_{4}^{3-}$ \\
940 & Asymmetric deformation $\mathrm{PO}_{4}^{3-}$ \\
\hline
\end{tabular}

The hydroxyapatite samples obtained were characterized by X-ray diffraction and analyzed by the Rietveld method (GSAS II program), with the structural data sheet of the Inorganic Crystal Structure Database (ICSD). The instrumental parameters were previously calculated using a NIST 660a LaB6 standard. The X-ray diffractograms of hydroxyapatites synthesized by precipitation as well as detailed information obtained through the Rietveld method are shown in Fig. 4. According to the diffractograms, only the crystalline phase of the hydroxyapatite $(\mathrm{Ca} / \mathrm{P}$ of 1.67$)$ was observed in the samples. It was identified by the crystal file ICSD 01-072-1243, which is according to the standard ISO BS 13779-3:2008 [53]. Considering this, Rietveld analysis was carried out and in Fig. 4 it is possible to observe the accurate fit between the experimental diffractogram (blue line) and diffraction pattern calculated by Rietveld refinement ( $\mathrm{x}$ dots). This was also manifested by the value of the difference between both, shown by the green line, which did not show high value at any point, which confirmed, in addition, the presence of the HAp as the only phase. The characteristic diffraction profile of the sample 1 presented intense and narrow peaks, a high percentage of crystallinity, with identification at $25.9^{\circ}, 31.6^{\circ}, 32.9^{\circ}$ and $33.9^{\circ}$ at $2 \theta$, corresponding to the reflections of planes 002, 002, 121 and 112, respectively. This result corroborates with other authors who obtained similar results; they synthesized calcium phosphate from the eggshell and were able to obtain hydroxyapatite using a calcination temperature range between 800 and $1250{ }^{\circ} \mathrm{C}$, and the most intense peak was observed near $2 \theta=31.7^{\circ}[47,62]$. The diffractogram of the
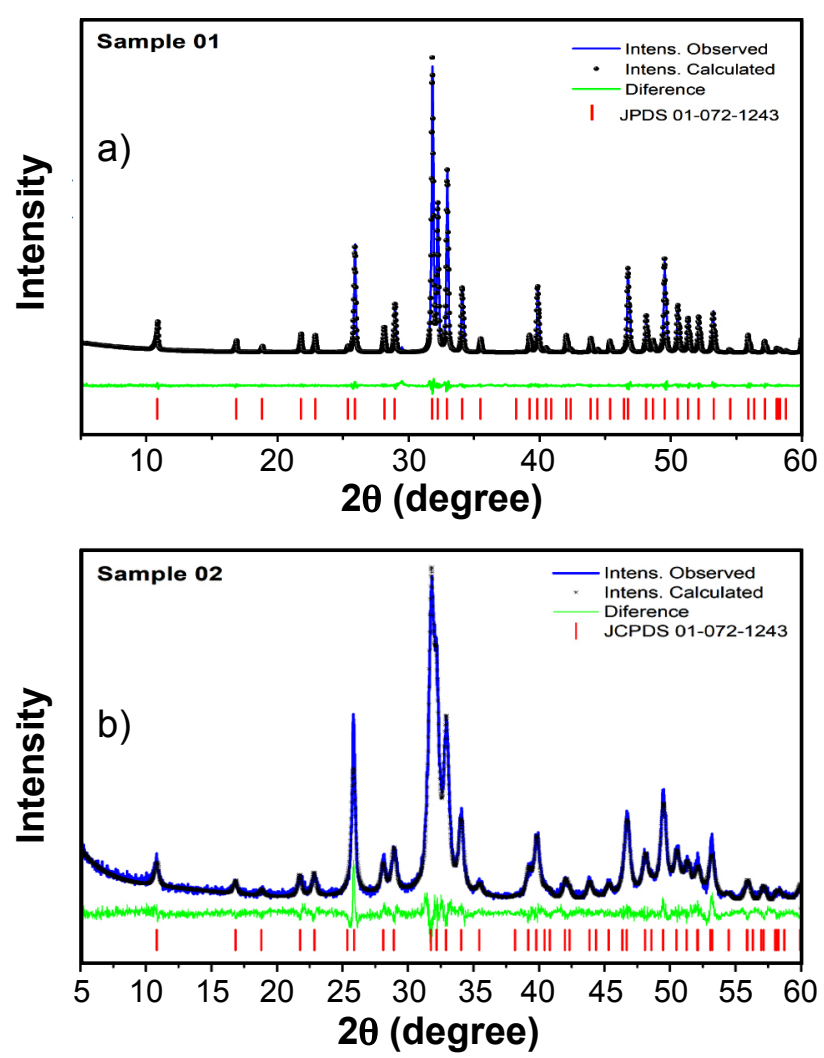

Figure 4: XRD patterns of hydroxyapatite: a) sample 1; and b) sample 2 .

[Figura 4: Difratogramas de raios X da hidroxiapatita: a) amostra 1; e b) amostra 2.] 
sample 2 presented broader peaks with lower intensity, showing a lower crystallinity, with diffraction positions similar to those shown in sample 1, according to Fig. 4. These characteristics resemble those of natural bone apatite. The quantitative analysis by Rietveld's refinement of the powder diffraction data can obtain valid information about the phase structural characteristic of the resulting powders, as can be observed in $[63,64]$.

Some studies $[12,30]$ investigated the influence of temperature to obtaining hydroxyapatite for biomedical purposes and verified that the calcination process improves the crystalline profile of the sample in which the increase in temperature raises its crystallinity; however, we observed that the calcination process with the same conditions in samples 1 and 2 resulted in different crystalline profiles, and the hydroxyapatite obtained from the precursor of biological origin showed a higher crystallinity. Aguilar et al. [49] studied the synthesis of hydroxyapatite with the use of a calcium carbonate of biological origin as a precursor, proving to be viable for the reactional pathway; the results corroborate with those obtained in this research. According to [65], the peak intensities demonstrate that the apatite crystallinity increases with the increasing of calcination temperature, influencing considerably the HAp microstructure. Also, the increase of calcination temperature promotes processes of atomic diffusion within the particles and consequently the reduction of pore sizes and numbers. The degree of crystallization of hydroxyapatites can be evaluated considering results shown in Table II, according to the parameters established in the X-ray diffraction equipment program (XRD-7000, Shimadzu), in which a degree of crystallinity of $94.99 \%$ in the sample 1 and $67.49 \%$ in the sample 2 was obtained, which demonstrated a more defined crystallinity for the HAp obtained from the eggshell.

Table II - Crystallographic parameters for the calculation of hydroxyapatite crystallization for both samples.

[Tabela II - Parâmetros cristalográficos para o cálculo da cristalização da hidroxiapatita para ambas as amostras.]

\begin{tabular}{ccc}
\hline Condition* & Sample 1 & Sample 2 \\
\hline Cristal I ${ }_{\text {cr }}(\mathrm{kcps} . \mathrm{deg})$ & 4.413 & 1.461 \\
Cristallinity & $94.99 \%$ & $67.49 \%$ \\
\hline * - Conditions of crystallinity calculation: reach: $5^{\circ}-60^{\circ}$; axis: $\theta-\theta ;$ Lorentz \\
correction: yes; $\theta$ M: $13.300^{\circ}$; parameter $K: 1.0 ;$ step: 10 ; width: 3 ; loop: 20.
\end{tabular}

The values of the crystallographic parameters obtained through refinement by the GSAS II program, with their respective concentrations of HAp phases (samples 1 and 2) are shown in Table III. It was observed the identification of a crystalline phase, with its respective crystalline system, spatial group, volume, percentage of crystalline phase, crystallite sizes and Rwp. All these data were obtained from the output information file on the statistical parameters of the refinements and confidence factors. Table III shows the results obtained from the XRD refinement of the samples 1 and 2. In [66], using the diffraction tomography and the Rietveld refinement method in different hydroxyapatites for evaluating their structures, it was observed results similar to those presented here. The crystallographic parameters corroborated results of scientific studies of hydroxyapatite. According to these values, the atomic distances were generally within the expected values, indicating absence of significant cationic or anionic substitutional impurities when evaluated by atomic occupational factors and by lattice parameters [31, 63, 67-70]. The numerical refinement adjustment values (weighted profile factor - Rwp) were lower than $12 \%$ which indicated a good fit between the data calculated by the theoretical model and the observed pattern $[52,62]$.

Table III - Crystallographic parameters of the hydroxyapatite (samples 1 and 2).

[Tabela III - Parâmetros cristalográficos da hidroxiapatita (amostras 1 e 2 ).]

\begin{tabular}{ccc}
\hline Parameter* & Sample 1 & Sample 2 \\
\hline $\mathrm{a}=\mathrm{b}(\AA)$ & 9.4201 & 9.4236 \\
$\mathrm{c}(\AA)$ & 6.8833 & 6.8898 \\
Crystallite size $(\mu \mathrm{m})$ & 0.122 & 0.0914 \\
Rwp & $2.36 \%$ & $11.85 \%$ \\
\hline *-Crystalline system: hexagonal (unit cell: hexagonal close-packed); space group: \\
P63/m; a,b,c- lattice parameters; percent crystalline phase: 100\%.
\end{tabular}

The size values of the hydroxyapatite crystallites (samples 1 and 2) are presented in Table III. Some studies $[31,71]$ showed that increasing the calcination temperature results in an increase in the size of the crystallite; however, the results showed that for the same calcination temperature $\left(800{ }^{\circ} \mathrm{C}\right)$, the crystallite size was larger for the sample 1 , obtained from the precursor of biological origin. The sizes of crystallites were calculated indicating that the larger crystallite sizes are associated with normal bone [72]. In the samples synthesized in this work we verified this larger size in sample 1, synthesized from the biological precursor. Rollo et al. [72] showed that the crystal structure of hydroxyapatite may indicate the quality of the trabecular bones, by identifying the size of the crystallite, microhardness, microstrain and calcium and phosphorus ratio in bones of three types: normal, osteopenic or osteoporotic. That means that Rietveld analysis should be a practical tool to evaluate the health of individuals through the diffraction study of their skeletal remains. Several parameters must be carefully controlled during the synthesis of hydroxyapatite aiming to obtaining a material with the ideal microstructure to promote the osteoinduction after its use. The thermal treatments involved during the synthesis are fundamental to form crystals well-ordered and with greater mechanical resistance [65].

From the Rietveld refinement the CIFs of the samples were obtained and later generated structural models through the VESTA program. In Fig. 5, the planes (100), (010), (001) and (111) of the hydroxyapatite samples (1 and 2) can be seen, with the representations of $\mathrm{Ca}$ (red), $\mathrm{P}$ (green), $\mathrm{O}$ (ashes) and $\mathrm{H}$ (blue) atoms in unit cells and the formation of 


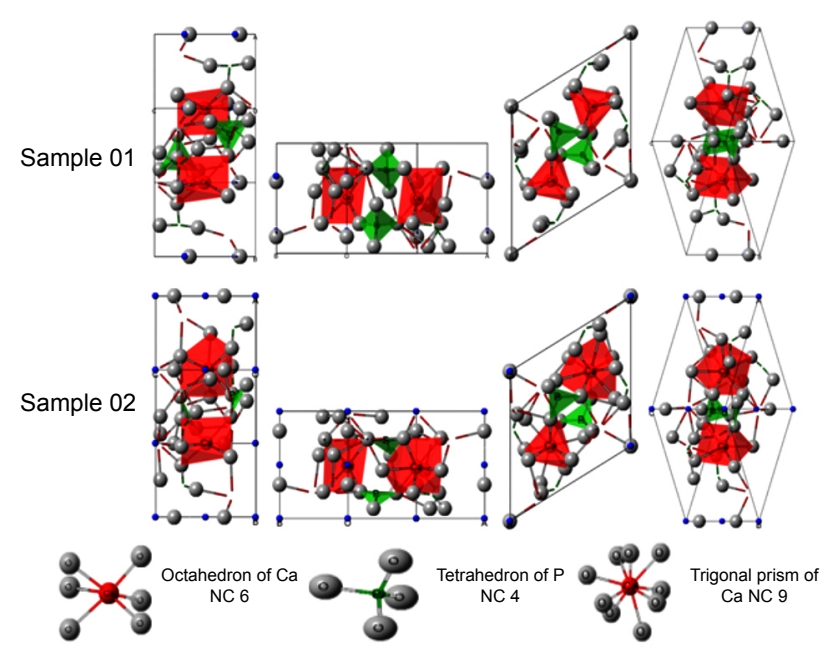

Figure 5: Crystal structures of hydroxyapatite shown with polyhedra, in red with central $\mathrm{Ca}$ atom and in green with central atom of $\mathrm{P}$ with oxygen atoms in their vertices.

[Figura 5: Estruturas cristalinas da hidroxiapatita mostradas com poliedros, em vermelho com átomo de Ca central e em verde com átomo central de P com átomos de oxigênio em seus vértices.]

Table IV - Atomic bonding distances ( $)$ of the microstructures formed in samples 1 and 2 .

[Tabela IV - Distâncias de ligação atômica (Å) das microestruturas formadas nas amostras 1 e 2.]

\begin{tabular}{|c|c|c|c|}
\hline $\begin{array}{l}\text { Bonding } \\
\text { type }\end{array}$ & $\begin{array}{c}\text { ISCD } \\
721243\end{array}$ & Sample 1 & Sample 2 \\
\hline & \multicolumn{3}{|c|}{ Octahedron } \\
\hline Ca1-O1 & 2.463 & 2.528 & 2.420 \\
\hline $\mathrm{Ca} 1-\mathrm{O} 2$ & 2.409 & 2.313 & 2.379 \\
\hline \multirow[t]{2}{*}{$\mathrm{Ca} 1-\mathrm{Ca} 2$} & 3.461 & 5.440 & 5.413 \\
\hline & \multicolumn{2}{|c|}{ Octahedron } & Trigonal prism \\
\hline $\mathrm{Ca} 2-\mathrm{O} 1$ & 2.707 & 2.535 & 2.545 \\
\hline $\mathrm{Ca} 2-\mathrm{O} 2$ & 2.351 & 2.342 & 2.417 \\
\hline \multirow[t]{2}{*}{$\mathrm{Ca} 2-\mathrm{O} 4$} & 2.344 & 2.341 & 2.357 \\
\hline & \multicolumn{3}{|c|}{ Tetrahedron } \\
\hline $\mathrm{P}-\mathrm{O} 1$ & 1.538 & 1.701 & 1.485 \\
\hline $\mathrm{P}-\mathrm{O} 2$ & 1.526 & 1.594 & 1.499 \\
\hline $\mathrm{P}-\mathrm{O} 3$ & 1.524 & 1.497 & 1.335 \\
\hline
\end{tabular}

tetrahedron of $\mathrm{P}$, octahedron and trigonal prism of $\mathrm{Ca}$. Based on the structural models, the distances among the atoms in the unit cells were calculated (Table IV) and compared with the distances present in the CIF (ISCD 721243) of the standard BS ISO 13779-3:2008, where small variations were observed. However, the distance between the calcium atoms (Ca1-Ca2) presented a considerable variation in relation to that of the CIF, corroborating with other studies $[73,74]$ that studied the microstructure of hydroxyapatite by Rietveld's refinement. These variations may be related to the degree of crystallinity observed previously, where the sample 2 had a lower crystallinity, and the formation of the trigonal prism was verified in the unit cell which caused a larger distortion of the structure. Based on X-ray diffraction results, it was possible to confirm that the hydroxyapatite obtained from the precursor of biological origin (eggshell) presented better microstructural characteristics when compared to that obtained by mineral precursor (calcium hydroxide).

\section{CONCLUSIONS}

The obtained results allowed concluding that the synthesis, from different precursors, by precipitation and subsequent calcination lead to the formation of the crystalline phase of hydroxyapatite. The synthesis of hydroxyapatite is influenced by several factors, among them its precursor. The biological precursor (eggshell) was more efficient for the synthesis of hydroxyapatite, when compared to the mineral precursor (calcium hydroxide), since it presented a higher crystalline phase percentage. Also, it showed higher morphological uniformity even with larger agglomerate sizes. With this information it can be highlighted that hydroxyapatite obtained by the eggshell showed characteristics that allow it to be used as biomaterial.

\section{ACKNOWLEDGMENTS}

The authors would like to thank the Coordination for the Improvement of Higher Education Personnel (CAPES), to the Post-Graduate Program in Materials Science and Engineering (PPG-CEMat-UFCG), to the Laboratory of Evaluation and Development of Northeastern Biomaterials - CERTBIO / UAEMA / CCT.

\section{REFERENCES}

[1] E.Y. Kawachi, C.A. Bertran, R.R. dos Reis, O.L. Alves, Quim. Nova 23 (2000) 518.

[2] A.C. Guastaldi, A.H. Aparecida, Quim. Nova 33 (2010) 1352.

[3] R.F. Bonan, P.R.F. Bonan, A.U.D. Batista, J.E. Oliveira, R.R. Menezes, E.S. Medeiros, Cerâmica 60 (2014) 402.

[4] A. Kumar, K. Biswas, B. Basu, J. Biomed. Mater. Res. A 103 (2015) 791.

[5] L.S.A.F. Oliveira, C.S. Oliveira, A.P.L. Machado, F.P. Rosa, Rev. Ciên. Méd. Biol. 9 (2010) 37.

[6] Y. Xu, J. Peng, X. Dong, Y. Xu, H. Li, J. Chang, Acta Biomater. 55 (2017) 249.

[7] X. Ren, Y. Feng, J. Guo, H. Wang, Q. Li, J. Yang, X. Hao, J. Lv, N. Ma, W. Li, Chem. Soc. Rev. 44 (2015) 5680.

[8] H. Khandelwal, S. Prakash, J. Miner. Mater. Charact. Eng. 4 (2016) 119.

[9] X.-P. Kong, X. Shen, J. Jang, X. Gao, J. Phys. Chem. Lett. 9 (2018) 947.

[10] G. Eğilmez, G.A. Süer, O. Özgüner, in: Manufacturing system, Ed. F.A. Aziz, IntechOpen (2012) 381.

[11] L.N. Miotto, L.M.G. Fais, A.L.R. Ribeiro, L.G. Vaz, J. Prosthet. Dent. 116 (2016) 102. 
[12] J. Zhao, J. Zhao, J. Chen, X. Wang, Z. Han, Y. Li, Ceram. Int. 40 (2014) 3379.

[13] W. Chen, Calphad 60 (2018) 98.

[14] M.H.M. do Nascimento, C.B. Lombello, Polímeros 26 (2016) 360 .

[15] S. Hahnel, A. Wieser, R. Lang, M. Rosentritt, Clin. Oral Implants Res. 26 (2015) 1297.

[16] M. Darnell, D.J. Mooney, Nat. Mater. 16 (2017) 1178.

[17] S. Dorozhkin, J. Funct. Biomater. 4 (2013) 209.

[18] F.M. Chen, X. Liu, Prog. Polym. Sci. 53 (2016) 86.

[19] N. Annabi, S.R. Shin, A. Tamayol, M. Miscuglio, M.A.

Bakooshli, A. Assmann, P. Mostafalu, J.Y. Sun, S. Mithieux,

L. Cheung, X. Tang, A.S. Weiss, A. Khademhosseini, Adv. Mater. 28 (2016) 40.

[20] K. Sadtler, A. Singh, M.T. Wolf, X. Wang, D.M. Pardoll, J.H. Elisseeff, Nat. Rev. Mater. 1 (2016) 16040.

[21] B.D. Ratner, A.S. Hoffman, F.J. Schoen, J.E. Lemons, Biomaterials science, $3^{\text {rd }}$ ed., Elsevier (2013).

[22] R.H. Doremus, J. Mater. Sci. 27 (1992) 285.

[23] H. Zhou, J. Lee, Acta Biomater. 7 (2011) 2769.

[24] M. Okada, T. Furuzono, Sci. Technol. Adv. Mater. 13 (2012) 064103.

[25] K.M. Galler, F.P. Brandl, S. Kirchhof, M. Widbiller, A. Eidt, W. Buchalla, A. Göpferich, G. Schmalz, Tissue Eng. Part A 24 (2018) 234.

[26] S. Husain, K.H. Al-Samadani, S. Najeeb, M.S. Zafar, Z. Khurshid, S. Zohaib, S.B. Qasim, Materials 10 (2017) 1. [27] D.D. Bosshardt, V. Chappuis, D. Buser, Periodontol. 200073 (2017) 22.

[28] N.M.P. da Silva, F. Espitalier, A. Nzihou, Kona Powder Part. J. 33 (2016) 219.

[29] M. Gutierres, M.A. Lopes, N.S. Hussain, A.T. Cabral, L. Almeida, J.D. Santos, Arq. Med. 19 (2005) 153.

[30] T.C.S. Pereira, G.A. Fernandes, Blucher Chem. Eng. Proc. 1 (2015) 2409.

[31] J.R. Lopes, J.A.C. de Oliveira, A. de A. Esteves, Foco 10 (2015) 55.

[32] M. Wei, A.J. Ruys, B.K. Milthorpe, C.C. Sorrell, J. Mater. Sci. Mater. Med. 16 (2005) 319.

[33] A. Taş, J. Am. Ceram. Soc. 84 (2001) 295.

[34] N.J. Bielemann, D.L.R. Novo, R.M. Pereira, J.E. Mello,

V.C. Costa, Quim. Nova 40 (2017) 785.

[35] E. Peón, C. Domínguez, H. Pérez, J.C. Galván, J.A.R. Ortiz, J.J. Pavón, Y. Torres, Rev. Cuba. Investig. Biomed. 36 (2017) 1.

[36] M. Pillaca, M. Moreno, A. Guzm, J. Quispe, U. Nacional, M. De San, Rev. Fac. Cien. Uni. Revciuni 13 (2010) 45.

[37] S. Ahmed, M. Ahsan, J. Sci. Ind. Res. 43 (2008) 501.

[38] D.A. Oliveira, P. Benelli, E.R. Amante, J. Clean. Prod. 46 (2013) 42.

[39] S. Nayar, A. Guha, Mater. Sci. Eng. C 29 (2009) 1326.

[40] C.V. de Souza, M.G. Lima, E. Leal, M. de Sá, E.M.J.A.

Pallone, R.H.G.A. Kiminami, A.C.F.M. Costa, $6^{\circ}$ Congr. Nac. Eng. Mecân. (2010).

[41] L.A.F. Vieira, M.D. Pinho, I.P. Pinheiro, S.N. Da Silva, J. Eng. Exact Sci. 3 (2017) 1159.
[42] W.J.B. De Sousa, R.C. Barbosa, M.V.L. Fook, P.T.D. Filgueira, A.F. Tomaz, Rev. Mater. 22 (2017) e-11902.

[43] B. Hosseini, S.M. Mirhadi, M. Mehrazin, M. Yazdanian, M.R.K. Motamedi, Trauma Mon. 22 (2017) e36139.

[44] V.S. Kattimani, P.S. Chakravarthi, N.R. Kanumuru, V.V. Subbarao, A. Sidharthan, T.S.S. Kumar, L.K. Prasad, J. Int. Oral Health 6 (2014) 15.

[45] S.C. Wu, H.C. Hsu, S.K. Hsu, Y.C. Chang, W.F. Ho, J. Asian Ceram. Soc. 4 (2016) 85.

[46] T. Rasool, S.R. Ahmed, I. Ather, M. Sadia, R. Khan, A.R. Jafri, in: Int. Mech. Eng. Congr. Expo., ASME, Texas (2015) 1.

[47] P. Kamalanathan, S. Ramesh, L.T. Bang, A. Niakan, C.Y. Tan, J. Purbolaksono, H. Chandran, W.D. Teng, Ceram. Int. 40 (2014) 16349.

[48] L.C. Gomes, B.C. Di Lello, J.B. Campos, M. Sampaio, Cerâmica 58 (2012) 448.

[49] M.S. Aguilar, J.B. Campos, B.C. Di Lello, F. Queiroz, N.C. Campos, $21^{\circ}$ Congr. Bras. Eng. Ciên. Mater., Cuiaba, (2014).

[50] B.H. Toby, J. Appl. Cryst. 34 (2001) 210.

[51] K. Momma, F. Izumi, J. Appl. Crystallogr. 44 (2011) 1272.

[52] R.A. Young, Introduction to the Rietveld method, Oxford Un. Press, USA (1995).

[53] A.S. Posner, A. Perloff, A.F. Diorio, Acta Crystallogr. 11 (1958) 308.

[54] S.V. Oliveira, S.N. Cavalcanti, G.P. Rabello, E.M. Araújo, M.V.L. Fook, $5^{\circ}$ Congr. Nac. Eng. Mecân. (2010).

[55] R.S.T. Manhães, U. Estadual, N. Fluminense, M. Corrêa, A. Lamego, Enc. Eng. Ciên. Mater. Inov. Est. Rio Janeiro, Campo dos Goyatacazes (2015).

[56] L.B. Caliman, S.N. da Silva, J.A. Junkes, V.P. Della Sagrillo, Mater. Res. 20 (2017) 413.

[57] F.L. Valente, L.C. Santos, R.V. Sepúlveda, G.P. Gonçalves, R.B. Eleotério, E.C.C. Reis, A.P.B. Borges, Ciên. Rural 46 (2016) 324.

[58] A.G.S. Azevedo, K. Strecker, H.F. Gorgulho, Cerâmica 61 (2015) 52.

[59] C. Chappard, G. André, M. Daudon, D. Bazin, Comptes Rendus Chim. 19 (2016) 1625.

[60] J.R.M. Ferreira, L.H.L. Louro, A.M. Costa, J.B. de Campos, M.H.P. da Silva, Cerâmica 62 (2016) 386.

[61] H.F.F. Brasil, P.M. Pereira, J.A.M. Correa, E.M.S. Rodrigues, $20^{\circ}$ Congr. Bras. Eng. Quím. (2015) 13471.

[62] J.C. De Araújo, L. Sena, I.N. Bastos, G.D. de A. Soares, Quim. Nova 30 (2007) 1853.

[63] K.P. Sanosh, M.C. Chu, A. Balakrishnan, T.N. Kim, S.J. Cho, Mater. Lett. 63 (2009) 2100.

[64] A. Sarkar, S. Kannan, Ceram. Int. 40 (2013) 6453.

[65] A.G.S. Azevedo, Rev. Univ. Vale Rio Verde 10 (2012) 297.

[66] S. Frolich, H. Leemreize, A. Jakus, X. Xiao, R. Shah, H. Birkedal, J.D. Almer, S.R. Stock, J. Appl. Crystallogr. 49 (2016) 103.

[67] R.K. Brundavanam, G. Eddy, J. Poinern, D. Fawcett, J. Mater. Sci. 3 (2013) 84. 
[68] J.C. De Araújo, I.N. Bastos, G.D. de A. Soares, Engevista 12 (2010) 41.

[69] W.S. Ferreira, C.M.R. Costa, S.R.B. Ferreira, S.F. Nunes, Engevista 19 (2017) 194.

[70] S. Kannan, F. Goetz-Neunhoeffer, J. Neubauer, J.M.F. Ferreira, J. Am. Ceram. Soc. 91 (2008) 1.

[71] P.Q. Franco, J. Silva, J.P. Borges, Ciên. Tecnol. Mater. 22 (2010) 57.
[72] J.M.D.A. Rollo, R.S. Boffa, R. Cesar, D.C. Schwab, T.P. Leivas, Procedia Eng. 110 (2015) 8.

[73] S. Lala, S. Brahmachari, P.K. Das, D. Das, T. Kar, S.K. Pradhan, Mater. Sci. Eng. C 42 (2014) 647.

[74] R.P. Singh, M. Singh, G. Verma, S. Shukla, S. Singh, S. Singh, Trans. Indian Inst. Met. 70 (2017) 1973.

(Rec. 03/04/2018, Rev. 27/06/2018, 04/09/2018, Ac. $14 / 10 / 2018)$ 